\title{
A VULGATA DA TRÍADE POÉTICA (LÍRICO, ÉPICO E DRAMÁTICO) NO ENSINO DE ROTEIRO PARA CINEMA E AUDIOVISUAL
}

\author{
THE VULGATE OF THE POETIC TRIAD (LYRIC, EPIC AND DRAMA) \\ IN THE TEACHING OF SCREENPLAY
}

\begin{abstract}
Alfredo SUPPIA*
Resumo: Lírico. Épico. Dramático. O que são essas categorias? Por que são reiteradamente referidas, com frequência, no ensino de roteiro para cinema e audiovisual (AV)? E por que a autoria dessas mesmas categorias é, não raro, atribuída à obra Arte poética (ou, simplesmente, Poética), de Aristóteles? Lírico, épico e dramático compõem a famosa tríade canônica, uma suposta matriz genérica da qual todos os gêneros literários emanam, ou da qual teriam se desenvolvido. Largamente aplicada ao estudo dos gêneros literários, a tríade canônica tem seu devido impacto nos estudos de cinema, notadamente na teoria e na prática do roteiro contemporâneo. É sabido que, embora em constante renovação, o campo do cinema e AV conserva modelos e axiomas provenientes de trabalhos pioneiros muito antigos, como a Poética, de Aristóteles, ou A república, de Platão, assim como de propostas e reflexões mais recentes, como as do formalismo russo. Este artigo pretende reexaminar a permanência dos "gêneros" lírico, épico e dramático no ensino do roteiro cinematográfico e AV, levando em conta parte da história dos gêneros literários e esforços predecessores de teorização, tanto no âmbito dos estudos literários, quanto no dos estudos de cinema e AV. Nesse sentido, pretendemos indagar por que as categorias do lírico, do épico e do dramático são reiteradamente referidas no ensino de roteiro para cinema e $\mathrm{AV}$, com sua "paternidade" frequentemente atribuída, por engano, à Poética, de Aristóteles. Investigaremos também qual a origem de tais termos, bem como sua aplicabilidade no ensino contemporâneo de roteiro.
\end{abstract}

Palavras-chave: Lírico. Épico. Dramático. Gêneros literários. Roteiro.

Abstract: Lyric. Epic. Drama. What are these categories? Why are they repeatedly referred to in the teaching of the screenplay? And why is the authorship of these same categories often attributed to Aristotle? Lyric, epic, and drama make up the famous canonical triad, an allegedly generic matrix from which all literary genres sprouted. Widely applied to the study of literary genres, the canonical triad has its due impact on film studies, notably in contemporary scriptwriting theory and practice. It is known that, although in constant renewal, the field of film and audiovisual media retains models and axioms from very pioneering works, such as Aristotle's Poetics or Plato's Republic, as well as more recent proposals and reflections such as those by the Russian formalists. This paper aims to review the three "prime" literary genres and revisit part of the history of literary genres, as well as previous theories on both film and literary genres, in order to scrutinize why the categories of "lyric", "epic", and "drama" are repeatedly referred to in the teaching of scriptwriting - and why the same categories are ascribed, by mistake, to Aristotle's Poetics. I will therefore comment on the origin of these terms and their applicability to the screenplay's contemporary teaching in this paper.

Key-words: Epic. Lyric. Drama. Literary genres. Screenplay.

\footnotetext{
* Professor de cinema da Universidade Estadual de Campinas (Unicamp). Doutor em Multimeios (Unicamp). Email: alsuppia@gmail.com. Orcid: https://orcid.org/0000-0003-0811-7118.
} 


\section{Introdução}

As teorias de gêneros literários e/ou dramáticos, adaptadas e transpostas ao contexto do cinema e do audiovisual (AV), continuam respondendo pelo grosso das atuais reflexões no campo do som+imagem em movimento. Resquícios de transformações históricas, ou ecos do passado dos gêneros, sobrevivem aqui e ali em definições de gêneros cinematográficos e AVs que ora privilegiam a forma, ora o conteúdo, ora o propósito, ora o efeito do pretenso grupo de obras sob escrutínio. Porém, raramente se resgata e se revisa algum modelo ou tipologia originário de outros campos do saber. Inspirado em trabalhos como o de Denizot (2010) e Chervel (1988/1989), entre outros, tentaremos proceder aqui a algumas indagações, sobretudo ao redor da seguinte pergunta: por que frequentemente se ensina que os "gêneros" lírico, épico e dramático são originários da Poética de Aristóteles? O objetivo central do presente artigo é proceder a uma revisão teórica de textos fundamentais no sentido de tentar elucidar, ao menos parcialmente, o problema da "vulgata da tríade canônica" (i.e. a atribuição a Aristóteles da "paternidade" dos gêneros lírico, épico e dramático). Em outras palavras, tentaremos recuperar um "itinerário" da tríade canônica ao longo de diferentes autores, para então buscar compreender melhor o problema da persistência da "vulgata da tríade" e do senso comum relativo aos "gêneros" lírico, épico e dramático. A metodologia do presente trabalho resume-se, portanto, a uma revisão teórica e/ou exegese de textos-chave.

Em tempo: não há qualquer problema no ensino ou na reflexão sobre os gêneros lírico, épico e dramático tout court. O problema colocado aqui é a frequente atribuição dessa tríade à Poética, de Aristóteles, bem como a frequente atribuição da "paternidade" exclusiva dos gêneros literários ao mesmo pensador.

\section{Começando a investigar o problema: a "escolarização" dos gêneros e alguns casos}

É suficiente aqui, por ora, compreender gêneros cinematográficos em linhas gerais e provisórias, nos termos de Doc Comparato (2009), por exemplo, para quem um "gênero" é uma "[c]lasse de assuntos artísticos da mesma natureza" (p. 485). Ou, melhor ainda, proceder como Nathalie Denizot (2010), que adota uma definição flexível da noção de gênero e despreza, momentaneamente, as hierarquizações possíveis - gêneros ou sub-gêneros resultam, por ora, como apenas gêneros, levando em conta a própria heterogeneidade constitutiva da noção. Denizot segue, assim, Karl Canvat (1988), para quem é justamente a frágil consistência teórica da noção de gênero que justifica seu continuado interesse.

Os gêneros literários, bem como os cinematográficos e AV, serão entendidos aqui como 
categorias mutáveis em função de seu contexto, de seu uso e de seu momento histórico. Para uma maior familiaridade com o panorama mais atual do que se entende por "gênero" cinematográfico ou AV, com foco na indústria ou no mercado do entretenimento, remetemos, seguindo o exemplo de Doc Comparato, ao Screenwriters guide, publicado nos EUA, o qual, segundo o próprio Comparato (2009), reconhece seis itens genéricos básicos: aventura, comédia, crime, melodrama, drama e outros (miscellaneous).

Não obstante, em certa medida, este artigo opera no mesmo diapasão do trabalho de Nathalie Denizot (2010), que, por sua vez, fez uma cartografia escolar da noção de "gênero" (literário) no sistema de educação francês entre 1802 e 2008. Denizot não discute os gêneros literários propriamente ditos, mas sua forma escolar, o que significa dizer, por exemplo, que não existe um teatro (ou uma dramaturgia) como objeto de ensino na escola, mas um "teatro escolar", ou "escolarizado", o qual responde a finalidades disciplinares particulares - da mesma forma que os discursos ou as narrativas acerca do teatro ou da dramaturgia, lidos e produzidos na escola, são "reconstruídos" com o fito de se tornarem "objetos escolares". Nesse sentido, "gêneros literários" (ou, em nosso caso, também cinematográficos ou audiovisuais), são reconstituídos em "gêneros literários escolares", da mesma forma submetidos a variações sincrônicas e diacrônicas. Em seu artigo, Denizot (2010) escrutina a origem e características das assim chamadas "vulgatas escolares": a vulgata balzaquiana (relativa à obra de Honoré de Balzac) e a vulgata da tragédia clássica, entre outras. Isso faz com que Denizot venha a afirmar que não há um, mas sim vários teatros escolares, por exemplo, da mesma forma que não há uma, mas várias vulgatas balzaquianas, reformuladas segundo configurações e usos disciplinares específicos. Sobre a tragédia, Denizot (2010) ainda assinala que "[a] escola constrói assim vulgatas, reduzindo pouco a pouco os autores de tragédias clássicas [na França] aos dois únicos Corneille e Racine, e a uma dezena de obras [...]" (p. 215, grifos da autora, tradução nossa). ${ }^{1}$

Denizot explica que ela mesma se insere num quadro teórico inspirado nos trabalhos de Chervel (1988/1989), o qual, por sua vez, coloca que as disciplinas de ensino são criações originais da escola com uma finalidade dúplice: a de instruir e aculturar as gerações mais jovens, funcionando como "mediações" (no original, "médiatisations") a serviço da juventude escolar em sua lenta progressão à cultura de uma sociedade global (CHERVEL, 1988/1989, apud DENIZOT, 2010). Ainda segundo Chervel, tal cultura escolar tende a se autonomizar e

\footnotetext{
${ }^{1}$ No original: "L'école construit donc des vulgates, réduisant peu à peu les auteurs de tragédies classiques aux deux seuls Corneille et Racine, et à une dizaine de pièces".
} 
se tornar uma cultura específica e original, a qual não deixa de contribuir, a seu modo, com a cultura da sociedade global (CHERVEL, 2005, apud DENIZOT, 2010). A “escolarização” à qual Denizot se refere em seu artigo segue a noção proposta por Kuentz (1972) e por Chervel (2006), consistindo em fenômenos de construção de objetos escolares a partir de objetos extra-escolares já existentes, um trabalho disciplinar específico para adaptar os gêneros à forma escolar e disciplinar (DENIZOT, 2010, p. 213-214).

Em nosso presente caso, algo equivalente poderia ser comentado em relação à Poética, de Aristóteles - no contexto universitário, muito provavelmente estaremos a falar de várias poéticas, e não apenas de uma -, bem como em relação a uma eventual genealogia, ou mesmo ontologia do roteiro cinematográfico e AV. Em tese, cursos universitários de cinema no Brasil podem eventualmente abrir espaço para a construção de "vulgatas" como esta intuída aqui: a associação da tríade canônica à Poética, de Aristóteles, bem como a atribuição da "paternidade" dos gêneros literários a esse pensador. Nas páginas seguintes, tentaremos discutir, portanto, algo que poderia vir a ser tratado como uma "vulgata poética", ou "vulgata aristotélica", no contexto dos estudos de roteiro para cinema e AV no país.

Da mesma forma que em Denizot (2010), estaremos a seguir tratando de uma tríade canônica escolarizada, isto é (grosso modo, é claro), gêneros poéticos (o lírico, o épico e o dramático) adaptados ao ensino de roteiro para cinema e AV, no contexto escolar/universitário. De todo modo, seguindo-se em frente, é notória a influência da teoria literária sobre os estudos de roteiro ou de teledramaturgia, uma influência vasta e contínua algo que, obviamente, não nos surpreende. Entretanto, causa curiosidade o fato de, à revelia dos avanços no domínio da teoria literária, os estudos de cinema e AV (no caso, mais especificamente, o ensino da teoria e da prática do roteiro) manterem alguns axiomas ou modelos longamente questionados, atualmente revistos, ou simplesmente abandonados. Esse talvez seja o caso do ensino dos gêneros lírico, épico e dramático em cursos, disciplinas e manuais de roteiro para cinema e AV.

Por exemplo - e aqui tomamos apenas um breve exemplo aleatório -, num pequeno livro não especificamente voltado aos estudos de cinema e $\mathrm{AV}$, porém dedicado a uma introdução sobre como analisar narrativas (objeto embutido ou indiretamente referido em teoria e prática do roteiro), Candida Vilares Gancho observa que: 
dramático. (GANCHO, 2006, p. 7, grifos da autora).

Primeiramente, é o caso de indagarmos em qual texto atribuído a Aristóteles é possível observar a formulação dessas tipologias - uma vez que, no caso da Poética, o pensador não distingue prosa de poesia (nem poderia, pois isso pouco faria sentido no provável contexto de sua época), nem se refere a uma eventual tipologia tripartite que porventura contivesse o gênero lírico. Em segundo lugar, lírico, épico e dramático são definições tributárias muito mais da forma ou do modo de enunciação do que propriamente do conteúdo de um dado texto.

A bem da verdade, mais autores parecem reconhecer que a tríade canônica foi uma formulação muito posterior a Aristóteles do que o contrário. Por exemplo, em seu livro de introdução aos gêneros literários, Angélica Soares (2000) oferece uma sucinta, porém arguta comparação da poética platônica com a poética aristotélica, terminando por alertar que, "[f]altando-nos o segundo livro da Poética, cuja perda é indicada por alusões a futuros escritos, feitas na parte da obra que chegou até nós, não temos o pensamento aristotélico sobre o lírico” (p. 11). Flávio de Campos, em seu Roteiro de cinema e televisão (2007), este sim um livro específico ao campo dos estudos de cinema, devidamente observa que:

\footnotetext{
Platão não fez referência ao gênero lírico - como tampouco fizeram, depois dele, o também grego Aristóteles (nascido em 384 a.C.) ou o latino Horácio (nascido em 65 a.C.), autores, em suas respectivas épocas, das obras mais significativas sobre narrativa. [...] $\mathrm{O}$ gênero lírico, como entendemos, só foi conceituado no início do século 17, pelo teórico espanhol Francisco Cascales. (CAMPOS, 2007, p. 66).
}

James Lodge, por exemplo, em A arte da ficção (2010), jamais vincula Aristóteles a uma divisão tripartite primeva dos gêneros poéticos. Syd Field (1995), autor de um dos mais populares manuais de roteiro, durante muito tempo um dos poucos traduzidos para o português no Brasil, evita qualquer menção à tríade clássica e, principalmente, a qualquer classificação dos gêneros por Aristóteles. Robert Edgar-Hunt, John Marland e Steven Rawle (2013), por sua vez, oferecem uma substanciosa introdução à linguagem do cinema que, muito embora cite Aristóteles e sua Poética com reverência, também passam ao largo de qualquer menção ao pensamento aristotélico como origem da tríade canônica (lírico, épico e dramático). Edgar-Hunt, Marland e Rawle oferecem ainda introduções muito úteis e apuradas ao pensamento de diferentes autores que já se debruçaram, mais recentemente (século XX), sobre a problemática dos gêneros e das narrativas - e.g. Ferdinand de Sausurre (2006), Roland Barthes (2012), E. M. Forster (2005), Vladimir Propp (2010), Tzvetan Todorov (1970; 1980; 2011; 2013) e Gérard Genette (1990), entre outros. 
Entrementes, alguns dos mais reputados manuais sobre roteiro para cinema e TV, publicados ao longo das últimas décadas e mesmo contemporaneamente, praticam a imprecisão da "vulgata da tríade canônica", deixando margem a algumas, senão muitas dúvidas. Por exemplo, em Story, de Robert McKee (2006), traduzido para o português, o autor sentencia que "Aristóteles nos deu os primeiros gêneros dividindo dramas de acordo com a carga de valor do final e o design da estória. [...] O resultado é (sic) seus quatro gêneros básicos: Trágico Simples, Trágico Complexo, Cômico Simples e Cômico Complexo" (p. 86). Não fica claro se McKee está se referindo à divisão que Aristóteles faz do gênero ou modo dramático, ou se exclui, proposital ou inadvertidamente, o gênero ou modo épico, ao qual poderiam ser afiliados os gêneros ou espécies da epopeia e do ditirambo. Sobre o que não há dúvida é que, de fato, não são quatro os "gêneros básicos" propostos por Aristóteles, como afirma McKee em seu manual Story, um livro amplamente vendido e citado como referencial para os estudos de roteiro de cinema e AV.

Em alguns casos, a bibliografia no contexto acadêmico, com foco sobre teoria literária, estudos de narrativa, teoria e prática do roteiro para cinema e AV, e mesmo ainda outros tópicos ou temas, vez ou outra ratificam essa ideia: a de que a Poética, de Aristóteles, teria dado origem à tríade canônica (os gêneros lírico, épico e dramático). As causas desse equívoco, podemos constatar, variam de obra para obra. Alguns autores de fato acreditam nessa explicação - supomos que tenham sido ensinados dessa forma e, portanto, apenas reproduzam esse conhecimento. Outros, talvez por algum "pecado" de síntese, uma argumentação mais apressada, ou por superestimarem a capacidade de seus leitores em estarem atentos a minúcias dessa natureza, acabam por expressar-se de uma forma que não desfaz o equívoco, ou apenas evita a questão. Esse talvez seja o caso, por exemplo, de Renata Pallottini (1998), que resume parte do pensamento do crítico Anatol Rosenfeld da seguinte forma:

\footnotetext{
[a]ssim, tomemos o texto de Rosenfeld; começa ele por expôr uma teoria dos gêneros a partir de Platão e Aristóteles. Por aí se reencontra o estudo dos modos de imitação e chegamos aos três gêneros: lírico, épico e dramático, sendo o lírico aquele em que o poeta fala por si, o dramático aquele em que o poeta faz aparecer personagens, e o épico aquele em que o poeta narra, em seu próprio nome, ou servindo-se de personagens (como faz Homero). (PALLOTTINI, 1998, p. 52-53).
}

É óbvio (assim cremos) que Pallottini não atribui a tríade canônica a Aristóteles e, no conjunto de seu livro, a autora demonstra conhecer as minúcias dessa tripartição genérica. Prova disso está já nas primeiras páginas de Introdução à dramaturgia (1998), dedicadas ao 
arco histórico que vai de Aristóteles a Hegel. No entanto, não podemos negar completamente que, no trecho acima citado, um leitor menos atento pode sim vir a ligar Platão e Aristóteles à tríade canônica, via o trabalho de Rosenfeld.

A situação se complica porque a própria obra à qual o trecho supracitado faz referência (ROSENFELD, 1985) também sugere algum nível de ligação da tríade canônica (o lírico, o épico e o dramático) à Poética, de Aristóteles. Em suas observações iniciais gerais, Anatol Rosenfeld começa por explicar que a classificação das obras literárias em gêneros tem suas origens n'A república (2016), de Platão. Segundo Rosenfeld, Sócrates assim define os três tipos de obras poéticas no livro III de A república:

[o] primeiro é inteiramente imitação. O poeta como que desaparece, deixando falar, em vez dele, personagens. "Isso ocorre na tragédia e na comédia". O segundo tipo "é um simples relato do poeta; isso encontramos principalmente nos ditirambos". Platão parece referir-se, neste trecho, aproximadamente ao que hoje se chamaria de gênero lírico, embora a coincidência não seja exata. "O terceiro tipo, enfim, une ambas as coisas; tu o encontras nas epopeias...". (ROSENFELD, 1985, p. 15, grifo nosso).

Saliente-se que Rosenfeld "atualiza" o ditirambo ou, melhor dizendo, classifica-o em retrospectiva, aproximando-o do que hoje conhecemos por gênero lírico, mesmo reconhecendo a inexatidão dessa eventual coincidência. Logo à página seguinte, Rosenfeld transfere o foco de sua argumentação para o pensamento de Aristóteles, discípulo de Platão.

\footnotetext{
A definição aristotélica, no 3o capítulo de Arte Poetica, coincide até certo ponto com a do seu mestre. Há, segundo Aristóteles, várias maneiras literárias de imitar a natureza: "Com efeito, é possível imitar os mesmos objetos nas mesmas situações, numa simples narrativa, ou pela introdução de um terceiro, como faz Homero, ou insinuando a própria pessoa sem que intervenha outro personagem, ou ainda, apresentando a imitação com a ajuda de personagens que vemos agirem e executarem eles próprios". Essencialmente, Aristóteles parece referir-se, neste trecho, apenas aos gêneros épico (isto é, narrativo) e dramático. No entanto, diferencia duas maneiras de narrar, uma em que há introdução de um terceiro (em que os próprios personagens se manifestam) e outro em que se insinua a própria pessoa (do autor), sem que intervenha outro personagem. Esta última maneira parece aproximar-se do que hoje chamaríamos de poesia lírica, suposto que Aristóteles se refira no caso, como Platão, aos ditirambos, cantos dionisíacos festivos em que se exprimiam ora alegria transbordante, ora tristeza profunda. Quanto à forma dramática, é definida como aquela em que a imitação ocorre com a ajuda de personagens que, eles mesmos, agem ou executam ações. Isto é, a imitação é executada "por personagens em ação diante de nós" (3o capitulo). (ROSENFELD, 1985, p. 16, grifo nosso).
}

A equivalência retrospectiva sugerida por Rosenfeld, por nós grifada nas duas situações, poderia ser discutida, embora não tenhamos qualquer pretensão de fazê-lo aqui - e voltaremos 
ao modelo de Platão, de forma mais detida, um pouco mais à frente. Por ora, vale destacar como a sugestão de uma equivalência entre o ditirambo e o que hoje entendemos por lírico, refletida numa análise da Poética, de Aristóteles, pode ser indicativa de um certo "automatismo" na persistência da ideia de que a tríade canônica tem sua paternidade atribuível ao fundador da escola peripatética e do Liceu. A persistência dessa ideia é ratificada, embora devidamente matizada pelo mesmo Rosenfeld, quando este esclarece que:

\begin{abstract}
[por] mais que a teoria dos três gêneros, categorias ou arquiformas literárias, tenha sido combatida, ela se mantém, em essência, inabalada. Evidentemente ela é, até certo ponto, artificial como toda a conceituação científica. Estabelece um esquema a que a realidade literária multiforme, na sua grande variedade histórica, nem sempre corresponde. Tampouco deve ela ser entendida como um sistema de normas a que os autores teriam de ajustar a sua atividade a fim de produzirem obras líricas puras, obras épicas puras ou obras dramáticas puras. A pureza em matéria de literatura não é necessariamente um valor positivo. Ademais, não existe pureza de gêneros em sentido absoluto. (ROSENFELD, 1985, p. 16, grifo nosso).
\end{abstract}

A oportuna explicação de Rosenfeld resgata a sabida arbitrariedade dos esquemas e sua frequente inexatidão, relativizando o automatismo que porventura venha a atribuir os gêneros lírico, épico e dramático à poética aristotélica. No entanto, podemos nos perguntar se as nuances e precauções sugeridas por esse autor foram sempre visitadas com a mesma atenção. Rosenfeld (1985) ressalva que "[a] teoria dos gêneros é complicada pelo fato de os termos 'lírico', 'épico' e 'dramático' serem empregados em duas acepções diversas" (p. 17): a substantiva (concernente ao modo através do qual uma dada fábula é representada), e a adjetiva (mais atinente aos traços estilísticos eventualmente identificados com um dado gênero). Nesse sentido, Rosenfeld segue também parte do pensamento de Frye (1973), ao comentar que:

[não] há grandes problemas, na maioria dos casos, em atribuir as obras literárias
individuais a um destes gêneros. Pertencerá à Lírica todo poema de extensão menor,
na medida em que nele não se cristalizarem personagens nítidos e em que, ao
contrário, uma voz central - quase sempre um "Eu" - nele exprimir seu próprio
estado de alma. Fará parte da Épica toda obra - poema ou não - de extensão maior,
em que um narrador apresentar personagens envolvidos em situações e eventos.
Pertencerá à Dramática toda obra dialogada em que atuarem os próprios personagens
sem serem, em geral, apresentados por um narrador. (ROSENFELD, 1985, p. 17,
grifo nosso).

Northrop Frye (1973), em Anatomia da crítica, também se refere à tríade canônica ao menos uma vez de forma um tanto quanto "automática" e resumida - malgrado a densidade do conjunto da obra, como em Rosenfeld (1985) -, relacionando sua origem aos gregos. Nos 
termos de Frye (1973): “[t]emos os três vocábulos genéricos: drama, epopeia e lírica, procedentes dos gregos, mas usamos os últimos dois principalmente como jargão ou gíria profissional, respectivamente por poema longo e curto (ou mais curto)" (p. 242).Vejamos aqui que, quando nos referimos aos "gregos" nesse contexto, o dos estudos literários, não raro estudantes em nível médio ou universitário, de literatura ou cinema, pensam em Platão e Aristóteles - e, talvez, mais provavelmente no segundo Justiça seja feita, assim como em Rosenfeld (1985), Frye confere nuance à tríade: [a] origem, porém, dos termos drama, epopeia e lírica sugere que é bastante simples
a idéia básica de gênero. O fundamento das distinções de gênero em literatura parece
ser o princípio da apresentação. As palavras podem ser representadas diante de um
espectador; podem ser cantadas ou entoadas; ou podem ser escritas para um leitor. A
crítica, notamos incidental e resignadamente, não tem nome para o membro isolado
da audiência de um autor, e a própria palavra "audiência" não cobre realmente todos
os gêneros, pois é levemente ilógico descrever os leitores de um livro como
audiência. A base da crítica genérica, em todo caso, é retórica, no sentido de que o
gênero é determinado pelas condições estabelecidas entre o poeta e seu público.
(FRYE, 1973, p. 242-243).

Sigamos em frente, por ora, para só depois retornarmos a Platão e Aristóteles, eventualmente fechando um círculo de reflexão. Afora algumas publicações, acadêmicas ou não, razoavelmente conhecidas e difundidas no ensino de roteiro para cinema e AV, é possível observar a presença da tríade canônica (o lírico, o épico e o dramático) também em algumas ementas de disciplinas de roteiro, em cursos universitários distribuídos pelo Brasil.

Se por ora nos faltam subsídios para determinar a prevalência ou não da vulgata dos gêneros clássicos no âmbito dos estudos de cinema e $\mathrm{AV}$, por outro lado é notável sua propagação em websites dedicados à introdução aos estudos narrativos e/ou ao roteiro para cinema e TV, os quais se pretendem educativos ou instrucionais. Por exemplo, no site Tertúlia Narrativa, um repositório virtual que traz conteúdos instrutivos de muito boa qualidade para estudantes e aspirantes a roteiristas, lê-se que:

[o] uso da palavra gênero na literatura refere-se à categorização de obras de acordo com características análogas de estilo, a forma e conteúdo. Já na Grécia Antiga, Aristóteles, em a Arte Poética, definia os gêneros literários em Épico (do qual são subgêneros os épicos, fábulas, epopeias, etc), Lírico (a poesia, a elegia, a ode, etc) e o Dramático (a comédia, a tragédia, etc). (SOUZA, 2018, online).

Por sua vez, o escritor Marcos Mota (2013), em seu site oficial, explica que "[o]s principais gêneros literários são: épico, dramático e lírico. [...] Todo gênero literário pode ser escrito na forma de verso ou prosa. Foi o filósofo grego Aristóteles que estabeleceu a divisão 
que persiste ainda hoje”. O site Brasil Escola, do portal UOL, de caráter notadamente educativo e popular, explica que: "Os gêneros literários podem ser classificados em três categorias básicas: gêneros épico, lírico e dramático. A teoria dos gêneros literários pode ser contada a partir da Antiguidade greco-romana, na Poética de Aristóteles"2.

Site de natureza equivalente, o InfoEscola começa por explicar, no verbete "gêneros literários", que as primeiras classificações dos gêneros narrativos teriam surgido na "Era Antiga", com os filósofos gregos Platão e Aristóteles. Logo em seguida, o site sentencia: “[t]odos os gêneros, porém, partem de uma classificação padrão, adotada desde a Antiguidade: narrativo ou épico; lírico e dramático. Deste tronco principal partem as ramificações menores, ou seja, os subgêneros". ${ }^{3}$ Outro site de orientação educativa, o Toda Matéria, traz em seu verbete sobre "gêneros literários", assinado pela Profa. Daniela Diana, as seguintes informações:

[a] classificação dos gêneros literários foi proposta, na antiguidade clássica, pelo filósofo grego Aristóteles (384 a.C.-322 a.C.), as quais foram divididas em: 1. Gênero Lírico: "palavra cantada". 2 Gênero Épico: "palavra narrada". 3. Gênero Dramático: "palavra representada". (DIANA, 2018, online).

O site Resumo Escolar - cujo subtítulo é “conteúdos para estudantes de todos os níveis, resumos de todas as disciplinas e muito mais!" - explica, em seu verbete "Gêneros Literários - Lírico, Épico, Dramático, Epistolar e Narrativo”, que

[f]oi Aristóteles quem iniciou a definição de gêneros literários em sua obra "Arte Poética", utilizando a teoria para descrever estilos diferentes de estrutura e conteúdo para um texto. Foi também na Grécia antiga que surgiram as primeiras poesias ocidentais, ocasionadas por manifestações esporádicas e espontâneas, até que começaram a se desenvolver entre os escritores da época.

Sob o ponto de vista de Aristóteles, que serve como base até hoje, os gêneros literários são um conjunto de obras que se identificam com um tipo específico de conteúdo e formato. Para distingui-los são usados critérios como o tipo de semântica usada, sintaxe, fonologia e até mesmo o contexto.

Os três primeiros gêneros literários reconhecidos na Grécia Antiga eram o Épico, o Lírico e o Dramático. O gênero lírico usava a poesia para expressar sentimentos, utilizando muito a primeira pessoa no verbo e nos pronomes. Como valorizava a musicalidade das palavras, se dividiu em Elegia, Ode, Écloga e Soneto. ${ }^{4}$

Neste caso, além de remeter a tríade à obra de Aristóteles, o site atribui a este a "paternidade" dos gêneros literários, ignorando qualquer menção ao mestre daquele, Platão.

\footnotetext{
${ }^{2}$ Disponível em: https://brasilescola.uol.com.br/literatura/generos-literarios.htm. Acesso em: 13 mai. 2020.

${ }^{3}$ Disponível em: https://www.infoescola.com/generos-literarios/. Acesso em: 13 mai. 2020.

4 Disponível em: https://www.resumoescolar.com.br/literatura/generos-literarios-lirico-epico-dramaticoepistolar-e-narrativo/. Acesso em: 13 mai. 2020.
} 
Por sua vez, o site Norma Culta, em seu verbete "Gêneros literários: tipos e características", começa por afirmar que:

[g]êneros literários são divisões feitas em obras literárias de acordo com características formais comuns, agrupando-as segundo critérios estruturais, contextuais e semânticos, entre outros. A divisão clássica remonta à Grécia antiga e define três gêneros literários: gênero lírico; gênero épico; gênero dramático. ${ }^{5}$

Em Medium.com, a Profa. Aryelle Almeida (2019) explica que:

Aristóteles, em sua Arte Poética, definiu aquilo que chamamos de gêneros literários. Os gêneros literários reúnem um conjunto de obras que apresentam características análogas de forma e conteúdo.

No gênero épico ou narrativo há a presença de um narrador, responsável por contar uma história na qual as personagens atuam em um determinado espaço e tempo.

Os textos do gênero lírico, que expressam sentimentos e emoções, são permeados pela função poética da linguagem. Neles há a predominância de pronomes e verbos na primeira pessoa, além da exploração da musicalidade das palavras.

Por último, de acordo com a definição de Aristóteles em sua Arte Poética, os textos dramáticos são próprios para a representação e apreendem a obra literária em verso ou prosa passíveis de encenação teatral. A voz narrativa está entregue às personagens, atores que contam uma história por meio de diálogos ou monólogos. (ALMEIDA, 2019, grifos da autora).

O site Educa+Brasil, aparentemente também orientado a estudantes do ensino médio e candidatos ao Enem, explica que "Na Grécia Antiga, o filósofo Aristóteles (384 a.C.-322 a.C.) realizou a primeira classificação dos gêneros literários em: Lírico, Épico e Dramático. Anos depois, o gênero épico passou a ser denominado como narrativo". ${ }^{6} \mathrm{O}$ site português.com.br explica também que " $[\mathrm{u}] \mathrm{m}$ dos primeiros pensadores a observar essa variedade de literatura foi Aristóteles. No seu livro A poética, o autor ressalta que existiam basicamente três gêneros literários, aos quais, hoje, chamamos 'gêneros clássicos': gênero lírico [...], gênero épico [...], gênero dramático [...]".7 No site Gestão Educacional, a Profa. Rafaela Mustafaga (s.d., online) ensina que "Em Arte Poética, Aristóteles definiu três gêneros literários como sendo os básicos, tanto que são utilizados até hoje: lírico, épico e dramático. Nessa classificação, só houve uma mudança, na qual o gênero épico passou a ser chamado de narrativo". Renato Luís de Castro, no site Curso Enem Gratuito, matiza um pouco mais o problema, embora também relacione a tríade canônica a Aristóteles e Platão:

\footnotetext{
${ }^{5}$ Disponível em: https://www.normaculta.com.br/generos-literarios/. Acesso em: 13 mai. 2020.

${ }^{6}$ Disponível em: https://www.educamaisbrasil.com.br/enem/lingua-portuguesa/generos-literarios. Acesso em: 13 mai. 2020.

${ }^{7}$ Disponível em: https://www.portugues.com.br/literatura/generos-literarios.html. Acesso em: 13 mai. 2020.
}

Revista Graphos, vol. 23, n 1, 2021 | UFPB/PPGL | ISSN 1516-1536 
[a]o longo da história, houve diversas classificações de gêneros literários, de maneira que não se pode determinar uma categorização de todas as obras seguindo um mesmo critério.

Precede, contudo, a classificação que provém da Grécia Antiga por meio das obras dos filósofos Platão (A República) e Aristóteles (A Poética) - narrativo ou épico, lírico e dramático - e que abarcam também outros vários subgêneros menores. (CASTRO, s/d., online).

A propósito, a vulgata da tríade poética é repetida com frequência também em conteúdos didáticos audiovisuais, as videoaulas ou lives, hoje um popular instrumento de apoio na formação de jovens do ensino médio e estudantes universitários. O site Descomplica (3.93 mi de inscritos, 77.663 visualizações, 10/05/19), em sua série "Quer que eu desenhe", no verbete "Gêneros literários", apresenta uma animação que inicia com um retrato estilizado de Aristóteles, sob voz over que explica:

[g]êneros literários foram criados há muito tempo; foi com Aristóteles, um figurão da filosofia, que lá na Antiguidade Clássica aconteceu a primeira tentativa de sistematização das formas literárias [...] Neste vídeo vamos focar nos gêneros literários. Três deles acabaram se destacando [...]: o épico, o lírico, e o dramático. ${ }^{8}$

A videoaula sobre gêneros literários no canal do Prof. Noslen (2.81 mi de inscritos, 295.779 visualizações, 18/03/2019) também explica que foi Aristóteles quem criou os primeiros gêneros literários: o épico, o lírico e o dramático ${ }^{9}$. No canal Pró Universidade Online (88,6 mil inscritos, 142.090 visualizações, 24/02/16), a Profa. Josi Motta, por sua vez, explica que "o filósofo grego Aristóteles dividiu tais manifestações em 3 categorias: épico, lírico e dramático". ${ }^{10}$ No canal X-tudante (81 inscritos, 233 visualizações, 08/07/2019), a apresentadora informa que "Aristóteles foi importante por fazer a primeira divisão dos gêneros literários. Ele dividiu os gêneros em épico, lírico e dramático, lá na Antiguidade Clássica". ${ }^{11} \mathrm{Na}$ videoaula sobre gêneros literários do canal Percurso Educacional (38, 3 mil inscritos, 5.142 visualizações, 23/02/2018), o Prof. Flávio de Castro explica que Aristóteles foi o primeiro a pensar os gêneros literários e a propor uma divisão tripartite dos mesmos: o épico, o lírico e o dramático. ${ }^{12} \mathrm{Na}$ videoaula "Literatura para o ENEM: Gêneros literários e o papel do protagonista", do canal $Q G$ do Enem (333 mil inscritos, 41.336 visualizações, 2020), o Prof. Marcos Laurindo confirma que foi Aristóteles, em sua Poética, quem começou a

\footnotetext{
${ }^{8}$ Disponível em: https://www.youtube.com/watch?v=5I66JIRAYJE. Acesso em: 13 mai. 2020.

${ }^{9}$ Disponível em: https://www.youtube.com/watch?v=9T7-gOm0nGk. Acesso em: 13 mai. 2020.

${ }^{10}$ Disponível em: https://www.youtube.com/watch?v=CfW1vYRKIXM. Acesso em: 13 mai. 2020.

${ }^{11}$ Disponível em: https://www.youtube.com/watch?v=nJ-xIe08M3o. Acesso em: 13 mai. 2020.

${ }^{12}$ Disponível em: https://www.youtube.com/watch?v=3678T9RhJkM. Acesso em: 13 mai. 2020.
} 
dividir os gêneros literários entre épico, lírico e dramático ${ }^{13}$. Por fim, em sua videoaula “Questão de gênero: lírico, épico ou dramático?”, do canal ProEnem (1,13 mil inscritos, 35.589 visualizações, 2020), o Prof. Walace Cestari afirma que Aristóteles “dividiu/organizou a arte literária em três grupos [...] o épico, o lírico e o dramático". ${ }^{14}$

Os exemplos supracitados dirigem-se sobretudo a estudantes candidatos ao exame do Enem, portanto não surpreende que procedam a determinadas simplificações ou condensações. As videoaulas são geralmente curtas, entre 5 e 20 minutos, sendo que apenas algumas atingem duração superior a uma hora. Em todos os casos, no entanto, o estilo enunciativo é semelhante: os professores, jovens e dinâmicos, dissertam sobre o tema com muita assertividade, e por meio de locuções curtas. Por mais que os exemplos sejam circunscritos a um determinado público jovem, convém não subestimar o poder de persuasão das videoaulas e sua permanência no repertório de estudantes que chegam finalmente a ingressar no ensino superior.

Em suma, os exemplos de reprodução da vulgata da tríade em conteúdos educativos ou instrucionais de livre acesso são numerosos e impossíveis de se esgotar aqui. Ao todo, consultamos apenas treze websites e oito conteúdos audiovisuais ou videoaulas. Onze websites foram taxativos sobre Aristóteles como criador dos gêneros épico, lírico e dramático, enquanto todas as videoaulas reproduziram, de alguma maneira, a mesma vulgata da tríade.

O mesmo não ocorre em sites educativos estrangeiros, também de acesso livre, como, por exemplo, alguns sites franceses (e.g. ÉtudesLittéraies, Superprof, ou Espace Français.com). O site da Universidade de Genebra, na Suíça, embora de natureza obviamente universitária, parece ter propósitos de divulgação gratuita de conhecimento e não incorre na remissão da tríade canônica a Aristóteles. Fornece informações resumidas, porém bastante acuradas no âmbito de seu verbete "méthodes et problèmes : les genres littéraires", de autoria de Laurent Jenny, professor do Depto. de Francês Moderno da Université de Genève. Jenny (2003) explica no site, a propósito das "triades des genres", o sistema de Batteux (1746) ${ }^{15}$, a "tríade romântica" e a "doxa contemporânea". Voltaremos a comentar esses tópicos e o site unige.ch um pouco mais à frente.

\section{A tríade poética em retrospectiva}

Antes, no entanto, e no sentido de melhor compreender a origem de toda essa

\footnotetext{
${ }^{13}$ Disponível em: https://www.youtube.com/watch?v=RC9ONoQwfBA. Acesso em: 13 mai. 2020.

${ }^{14}$ Disponível em: https://www.youtube.com/watch?v=L_t1 Kp4HV7g. Acesso em: 13 mai. 2020.

${ }^{15}$ Que revisita e atualiza o modelo aristotélico para adequar o gênero "lírico".
} 
controvérsia, o porquê de a tríade canônica lírico-épico-dramático ser atribuída à Poética, de Aristóteles, e permanecer tão em voga em diversos momentos de aprendizagem do roteiro para cinema e AV no Brasil, façamos um breve percurso retrospectivo. Em A república, Platão elenca três tipos de poesia ou ficção imitativa: um dramático, um épico, e um misto.

Há um primeiro tipo de poesia e de ficção inteiramente imitativa que compreende, como disseste, a tragédia e a comédia; um segundo, em que os fatos são relatados pelo próprio poeta - tu a encontrarás, sobretudo, nos ditirambos -; e, enfim, um terceiro tipo formado pela combinação dos dois precedentes, utilizado principalmente na epopeia em muitos outros gêneros. (PLATÃO apud STALLONI, 2001, p. 21).

Quadro 1 - Representação da Mimesis ou imitação.

\begin{tabular}{|c|c|c|c|}
\hline \multicolumn{2}{|c|}{ Mimesis ou imitação } \\
\hline $\begin{array}{c}\text { Enunciação zero } \\
\text { A palavra representada }\end{array}$ & $\begin{array}{c}\text { Enunciação direta } \\
\text { A palavra narrada }\end{array}$ & \multicolumn{2}{c|}{$\begin{array}{c}\text { Enunciação mista } \\
\text { A palavra narrada e representada }\end{array}$} \\
\hline Dramático & Narrativo & \multicolumn{2}{|c|}{ Narrativo-dramático } \\
\hline Tragédia & Comédia & Ditirambo & $\begin{array}{c}\text { Demais gêneros } \\
\text { narrativos }\end{array}$ \\
\hline
\end{tabular}

Fonte: Adaptado de Stalloni (2001, p. 22).

Como bem explica Yves Stalloni (2001, p. 22), Platão sugere um modelo triádico em que (1) uma arte da imitação - o teatro - manifesta-se em comédias ou tragédias; (2) uma arte da narrativa pura manifesta-se no ditirambo que, por sua vez, expressa-se em verso; e, (3) finalmente, uma arte mista manifesta-se na epopeia, cujo melhor exemplo seria a obra de Homero.

Aristóteles, por sua vez, proporá um modelo binário, e não trinitário. Em sua Poética (2008), talvez até hoje uma das mais reputadas obras originadoras dos estudos literários, Aristóteles procederá a um estudo comparativo, normativo e valorativo do que ele definiu como os dois grandes gêneros poéticos: o dramático, baseado na mimese (imitação), e o épico, baseado na diegese (narração). Em sua Poética, Aristóteles assume a seguinte tarefa:

Falaremos da arte poética em si e das suas espécies, do efeito que cada uma destas espécies tem; de como se devem estruturar os enredos, se se pretender que a composição poética seja bela; e ainda da natureza e do número das suas partes. E falaremos igualmente de tudo o mais que diga respeito a este estudo, abordando, naturalmente, em primeiro lugar, os princípios básicos. (ARISTÓTELES, 2008, 1447a p. 37).

Vejamos que, na Poética, Aristóteles (2008) refere-se a "espécies" de textos (a epopeia, a tragédia) como se estivesse se referindo ao que hoje entendemos por gênero. Em algum 
momento, e em alguma medida, "gênero" e "espécie" vieram a se tornar termos intercambiáveis. No entanto, o que mais nos interessa aqui é a frequente atribuição, a Platão e Aristóteles, do modelo trinitário dos gêneros poéticos: o lírico, o épico e o dramático.

\section{Genette, os arquitextos e o engano da tríade}

Quem melhor destrinchou esse "hábito", por assim dizer, talvez tenha sido Gérard Genette, em seu Introdução ao arquitexto (1990). Como bem observa Genette (1990), na Poética, de Aristóteles, o lírico não é objeto de atenção, sequer é proposto como uma categoria em relação ao épico e ao dramático. O mesmo se aplica a Platão, que propunha um modelo trinitário (composto pelas categorias do épico, do dramático e do misto), em que o suposto gênero lírico não tinha, por ora, razão de existir.

Genette (1990) resgata a história dos modelos platônico e aristotélico e investiga uma série de autores dedicados ao estudo dos gêneros literários, no sentido de esclarecer a confusão proveniente da imposição destes que seriam os três gêneros primevos da expressão poética: o lírico, o épico e o dramático - ou, como em alguns autores (e.g. August Wilhelm Schlegel), o épico, o lírico e o dramático, nessa ordem. ${ }^{16}$ Genette sugere que o motor dessa controvérsia possa dever-se a uma longeva confusão entre as categorias de modo e gênero.

\footnotetext{
Em Platão, e ainda em Aristóteles, vimo-lo, a divisão fundamental tinha um estatuto bem determinado, pois se reportava explicitamente ao modo de enunciação dos textos. Na medida em que eles eram tomados em consideração (muito pouco em Platão, mais em Aristóteles), os géneros propriamente ditos vinham repartir-se entre os modos, segundo o ponto até o qual relevavam desta ou daquela atitude de enunciação: o ditirambo, da narração pura, a epopeia da narração mista, a tragédia e a comédia da imitação dramática. Mas essa relação de inclusão não impedia o critério genérico e o critério modal de se manterem absolutamente heterogéneos, e de estatuto radicalmente diferente: cada género se definia essencialmente por uma especificação de conteúdo que nada prescrevia na definição do modo do qual relevava. A divisão romântica e pós-romântica, em contrapartida, encara o lírico, o épico e o dramático não já como simples modos de enunciação, mas como verdadeiros géneros, cuja definição comporta já inevitavelmente um elemento temático, por muito vago que seja. (GENETTE, 1990, p. 76-77, grifo do autor).
}

Mais à frente em sua argumentação, Genette explica que a transmutação das categorias modais de lírico, épico e dramático em gêneros não apenas é equivocadamente atribuída a Aristóteles, mas também resulta de uma interpretação enviesada da Poética:

\footnotetext{
${ }^{16}$ Genette (1990) explica que Hegel retoma A. W. Schlegel adotando o esquema "épico-lírico-dramático" (p. 5460), ao passo que Schelling inverte a ordem dos primeiros termos: a arte começa pela subjetividade lírica (GENETTE, 1990, p. 58).
} 
[a] diferença estrutural entre o sistema de Aristóteles e o das teorias românticas e modernas é que estas últimas se confinam geralmente a um esquema de inclusões unívocas e hierarquizadas (as obras nas espécies, as espécies nos géneros, os géneros nos "tipos"), enquanto o sistema aristotélico - por rudimentar que noutros pontos seja - é implicitamente tabular, supõe implicitamente um quadro de (pelo menos) dupla entrada, onde cada género releva ao mesmo tempo (pelo menos) de uma categoria modal e de uma categoria temática: a tragédia, por exemplo, é (a este nível) definida no mesmo movimento como essa-espécie-de-obras-de-tema-nobreque-se-representam-no-palco, e como essa-espécie-de-obras-que-se-representam-nopalco-cujo-tema-é-nobre, a epopeia ao mesmo tempo como uma acção-heróicacontada e como a narrativa-de-uma-acção-heróica, etc. As categorias modais e temáticas não têm entre elas nenhuma relação de dependência, o modo não inclui nem implica o tema, o tema não inclui nem implica o modo, e deve ser pacífico que a apresentação espacial do quadro poderia ser invertida, com os objectos em abcissa e os modos em ordenada; mas os modos e os temas, ao cruzarem-se, co-incluem e determinam os géneros. (GENETTE, 1990, p. 87).

O trecho de Genette, vale lembrar, remete-nos também à explicação de Rosenfeld (1985), que destacou as acepções substantiva e adjetiva das categorias originalmente propostas por Aristóteles. Assim sendo, poderíamos compor o seguinte quadro ilustrativo:

Quadro 2 - Modelo aristotélico presente na Poética.

\begin{tabular}{|c|c|c|c|}
\hline OBJETO & MODO & DRAMÁTICO & NARRATIVO \\
\hline SUPERIOR & tragédia & epopeia \\
\hline \multicolumn{2}{|c|}{ INFERIOR } & comédia & paródia \\
\hline
\end{tabular}

Fonte: Extraído de Genette (1990, p. 30).

Genette recorre também ao modelo de Goethe com aparente simpatia, para tentar desfazer algo da "névoa" que teria se formado sobre o modelo aristotélico a partir do final do classicismo e da emergência do romantismo. Segundo Genette, embora Goethe (1819) mantivesse a tríade modal lírico-épico-dramático com a equívoca descendência de Aristóteles, o romântico alemão, por sua vez, opunha às simples “espécies poéticas” (Dichtarten) gêneros particulares como o romance, a sátira ou a balada - três modos poéticos (Dichtweisen), os quais poderiam agir quer em conjunto, quer separadamente (GENETTE, 1990, p. 77-78).

A oposição entre Dichtarten e Dichtweisen recobre com precisão a distinção entre géneros e modos, e é confirmada pela definição puramente modal do epos e do drama. Em contrapartida, a do lirismo é sobretudo temática, o que retira pertiência ao termo Dichtweisen, e nos reenvia à noção mais indecisa de Naturform. (GENETTE, 1990, p. 78, grifos no original).

A despeito do que possamos reter aqui a partir do modelo de Goethe, convém termos 
em mente, ainda, o seguinte alerta de Genette, sobre o fato de que:

[...] a relacionação entre a categoria do género e aquela a que chamo por seu nome o "modo" (o termo de "género" propriamente, ao fim e ao cabo, não aparece na Poética) não é de simples inclusão, ou, mais precisamente, não é de simples inclusão. Há e não há inclusão, ou melhor, há (pelo menos) dupla inclusão, ou seja, intersecção. (GENETTE, 1990, p. 86, grifos do autor).

Aqui, Genette acena com a ideia de que, a despeito de sua utilidade heurística ou hermenêutica, a história da poética e, particularmente, das tipologias genéricas, parece debater-se secularmente com a ingrata tarefa de compartimentar objetos que constantemente se superpõem, se entre-permeiam, ou simplesmente se "visitam", mutuamente. Como se se tentasse separar águas com redes de pesca - sobre esse problema apontado por Genette, remetemos ao fenômeno da "escolarização" investigado por Denizot (2010), bem como ao conceito de amphitextualité ("anfitextualidade") proposto pela mesma autora, e do qual trataremos um pouco mais à frente. Pouco antes de concluir seu percurso investigativo, de Platão e Aristóteles à teoria literária na modernidade, Genette constata que:

[t]odas as teorias evocadas até aqui constituíam - de Batteux a Staiger - outros
tantos sistemas inclusivos e hierarquizados, como o de Aristóteles, no sentido de que
os vários géneros poéticos neles se repartiam sem resto entre as três categorias
fundamentais, como se outras tantas subclasses: sob o épico, epopeia, romance,
novela, etc.; sob o dramático, tragédia, comédia, drama burguês, etc.; sob o lírico,
ode, hino, epigrama, etc. Mas tal classificação conserva-se ainda, em muito,
elementar, já que no interior de cada um dos termos da tripartição motivada os
géneros particulares se encontram em desordem, ou pelo menos se organizam - de
novo como em Aristóteles - segundo um outro princípio de diferenciação,
heterogéneo àquele que motiva a própria tripartição: epopeia heróica vs. romance
sentimental ou "prosaico", romance longo vs. novela curta, tragédia nobre vs.
comédia familiar, etc. Sente-se, pois, por vezes a necessidade de uma taxinomia
mais cerrada, que ordene segundo o mesmo princípio até a repartição de cada
espécie. (GENETTE, 1990, p. 64-65).

Mais à frente, Genette reconhecerá uma certa superioridade no antigo sistema aristotélico, de certa maneira mais arguto e funcional que os demais (e numerosos) modelos que o sucederam.

Ora parece-me hoje que tudo considerado e se é preciso (sê-lo-a?) um sistema, apesar da exclusão que faz, hoje injustificável, dos géneros não representativos, o de Aristóteles (mais uma vez torniamo alla antico...) é na sua estrutura superior (quer dizer, evidentemente, mais eficaz) à maioria daqueles que se lhe seguiram, e que fundamentalmente vicia a sua taxinomia inclusiva e hierárquica, que de cada vez bloqueia no seu conjunto todo o jogo e o conduz a um impasse. (GENETTE, 1990, p. 88).

O "automatismo" da associação da tríade canônica (o lírico, o épico e o dramático) à Revista Graphos, vol. 23, n 1, 2021 | UFPB/PPGL | ISSN 1516-1536 
Poética, de Aristóteles, talvez se deva a um "salto" pedagógico ou a um excesso de síntese. Se praticamente todos os cursos de teoria e prática do roteiro para cinema e AV partem da Poética, de Aristóteles, e, em algumas vezes, incluem A república, de Platão, é provável que poucos, ou virtualmente nenhum, incorpore alguma nota ou comentário sobre o sistema de Batteux, ou proceda a um exame mais aprofundado da tríade romântica. Como bem lembra Jenny (2003), em sua obra o abade Batteux (1746) revela-se mais aristotélico do que o próprio Aristóteles - ele não apenas mantém o princípio imitativo como princípio geral da arte literária, como também estende o mesmo princípio à poesia lírica.

Jenny explica também, didática e sucintamente, que o romantismo alemão, por sua vez, vai instalar de forma duradoura a tríade lírico-épico-dramático, destacando-a do princípio imitativo (Aristóteles e Batteux). Ainda segundo Jenny, isso produz outra mudança importante: o sistema clássico dos gêneros configurava-se segundo modos de enunciação dos arquétipos genéricos e dos universais poéticos, desprezando a história, no contexto de uma tipologia abstrata e essencialista. Com o romantismo, passa-se então a concepções evolucionistas e históricas dos gêneros. Haverá, assim, na esteira do romantismo, variações da tríade entre os pensadores alemães, como no caso dos irmãos Schlegel (filhos do tradutor de Batteux), que historicizam a noção de gênero pela oposição entre clássico e romântico. Os gêneros não são, nesse novo quadro, nem naturais nem atemporais, mas produtos de um determinado lugar e tempo. Numa nota de 1797, Friedrich Schlegel postula a forma lírica como subjetiva, a dramática como objetiva, e a épica como subjetiva-objetiva (COMPAGNON, 2001). Segundo Jenny, tais variações colocarão, não obstante, o gênero dramático como uma síntese dos outros dois (épico e lírico), segundo um esquema histórico dialético (2003).

Jenny comenta também a "doxa contemporânea" a propósito dos gêneros poéticos, na qual ele constata que a tríade canônica chega até nós de forma mais ou menos reconfigurada [réamenagée]. Sem sobrevalorizar um gênero em relação a outro, teríamos assim a tendência, contemporaneamente, a opor empiricamente três macro-gêneros: o romance, a poesia e o teatro. Essa grade, ainda que aparente ser evidente, mistura critérios heterogêneos (JENNY, 2003). E parece-nos claro que, ante um eventual interesse em se formular uma genealogia desses macro-gêneros, a tríade épico-lírico-dramático resulta não apenas conveniente, mas necessária.

Anterior ao exemplo do conteúdo produzido por Jenny, o curso de M. Antoine Compagnon (2001), "Théorie de la littérature: la notion de genre", igualmente disponível 
online, também passa ao largo de qualquer associação direta de Aristóteles à tríade canônica, fornecendo conteúdo teórico sintético, porém detalhado, acerca de uma história dos gêneros literários. Em sua "Quatrième leçon: Poétique des genres: Aristote", Compagnon (2001) assinala que Platão implicitamente limitou-se à poesia representativa ou à ficcionalidade. Apenas a representação dos eventos era considerada, não a descrição de objetos. A poesia lírica era ignorada, da mesma forma que ela não será mencionada por Aristóteles. Para ambos (Platão e Aristóteles), ela (a poesia lírica) permanece fora de campo, o que nos remete à centralidade do objeto - dos seres humanos que agem. Nesse aspecto, a poética de Platão e Aristóteles, também segundo Compagnon, é essencialista. Em sua "Septième leçon: Esthétique des genres : la triade romantique", Compagnon (2001) explica que, na tríade romântica, os gêneros são oriundos de princípios de causalidade inerentes à literatura, mantendo uma natureza interna. A problematização passa a debruçar-se sobre o passado, mas redunda sendo finalista, visando a justificar o presente, notadamente a literatura romântica. As classificações genéricas são, assim, confrontadas com a história. Segundo Compagnon (2001), "[...] a estética romântica é também uma filosofia da história". ${ }^{17}$

Podemos supor que, ao longo desse processo reflexivo e histórico, entre o sistema proposto por Batteux e o Romantismo alemão, talvez o "automatismo" da associação entre a Poética, de Aristóteles, e os gêneros épico, lírico e dramático tenha ganho substância, por motivos precisos os quais não teremos tempo nem subsídios para esmiuçar neste artigo. Não obstante, convém perguntar se os estudos de cinema e AV - incluso nesse campo o quadrante da teoria e prática do roteiro - não seriam excessivamente tributários ou reverentes aos ideais românticos, ou a vulgarizações dos ideais românticos.

Mas façamos justiça. Manuais de roteiro mais recentes, de autores brasileiros, têm sido mais precisos e bem fundamentados no que diz respeito à incorporação de subsídios do campo dos estudos literários ou dos gêneros poéticos. Roberto Guimarães, por exemplo, não apenas evita o equívoco da referência a Aristóteles como "pai" da tríade canônica, como resume muito bem a origem dos gêneros lírico, épico e dramático.

\footnotetext{
Antes de ser um texto técnico, o roteiro é um texto do gênero dramático. É preciso, então, dizer em algumas palavras o que são os gêneros poéticos, para entendermos o que significa gênero dramático. Os gêneros poéticos são o épico, o lírico e o dramático. Essa divisão tripartite da poética aparece na Alemanha, no século XVIII (Staiger, 1993, p. 16), e é muito útil para fazermos uma aproximação da forma como deve ser escrito um texto do gênero dramático. Não discutiremos se esta é a melhor representação dos gêneros literários. Vamos encontrar na Estética de Hegel (Hegel, 1980, p. 375) as definições desses gêneros. (GUIMARÃES, 2009, p. 30).
}

\footnotetext{
${ }^{17}$ No original: "l'esthétique romantique est aussi une philosophie de l'histoire".
} 
É assim que Guimarães introduz, de forma didática e sintética, porém precisa, uma explicação sobre a tão difundida tríade dos gêneros poéticos. Para maiores detalhes, vale o apelo de Guimarães para que examinemos a obra de Hegel (1980). Mesmo porque, como explica o próprio Staiger (1977), citado por Guimarães: "Há razões para aceitarmos sem mais análise essa divisão tripartida em lírico, épico e dramático? Irene Behrens prova que essa divisão só apareceu na Alemanha nos fins do século XVIII. E na época não correspondia ainda à nossa idéia de gêneros, mas designava determinados padrões poéticos" (STAIGER, 1977, p. 5).

Não dispomos aqui do tempo e do espaço adequados para uma investigação mais profunda das complexidades tipológicas dos gêneros no período romântico, ou na obra de autores como Goethe, Hegel, Schiller e os irmãos Schlegel, entre outros. Entretanto, cremos ser importante retomar o trabalho de Denizot (2010) sobre a escolarização dos gêneros literários na França, a fim de esboçar um eventual paralelo com a vulgarização da tríade canônica nos estudos de cinema e AV no Brasil.

\section{Escolarização e amphitextualité}

Como bem observa Denizot, o processo de "escolarização" disciplinar de um gênero literário (em nosso caso, de gêneros poéticos aplicados a uma introdução histórica da prática do roteiro cinematográfico) implica um trabalho de seleção que opera notadamente sobre o corpus dos textos, o qual também é evocado no que diz respeito aos "pedaços escolhidos" tal seleção, explica Denizot (2010), funciona igualmente como um filtro que retém apenas aquilo que serve às finalidades disciplinares. Para exemplificar essa tese, Denizot enfoca o gênero da tragédia clássica, aparentemente bem estabilizado no contexto escolar há muito tempo. Denizot salienta que "[o] estudo dos currículos escolares da tragédia mostra o quanto cada época contruiu e reconstruiu a 'sua' tragédia clássica, dando origem assim a diversas vulgatas escolares, movediças em função dos usos disciplinares" (2010, p. 214, grifo da autora, tradução nossa). ${ }^{18}$ No entanto, o processo não se esgota no trabalho de "seleção" mencionado por Denizot - a este soma-se um processo igualmente importante, o de "sincretização", o qual nos leva a amalgamar quadros e tradições, por vezes diversas, no sentido de se construir um novo paradigma disciplinar. Segundo Denizot (2010, p. 215), o

\footnotetext{
18 No original : "L'étude des corpus scolaires de la tragédie montre en effet combien chaque époque a construit et reconstruit "sa” tragédie classique, donnant ainsi naissance à plusieurs vulgates scolaires, mouvantes selon les usages disciplinaires".
} 
modelo escolar do gênero empresta, segundo as épocas, tanto de quadros tradicionais, como a retórica e a poética, quanto da história da literatura ou das ciências da linguagem. A definição escolar do gênero nos currículos mais recentes leva em conta, portanto, as definições linguísticas e discursivas dos gêneros do discurso, notadamente influenciada pelo pensamento de Bakhtin, integrando, desta forma, os gêneros argumentativos/textuais. Não obstante, os mesmos currículos conservam quadros tradicionais da poética clássica:

[...] é assim que subsiste ainda o modelo da "tríade" (épico, lírico e dramático, reformulado para integrar os gêneros da prosa em romance, poesia e teatro), a qual, calcando-se na tradição retórica dos três gêneros (judiciário, deliberativo e demonstrativo), é chegada ao século XIX como um quadro essencial para a categorização dos gêneros no âmbito dos trabalhos escolares [...] (DENIZOT, 2010, p. 215 , tradução nossa). ${ }^{19}$

Isso talvez explique, senão completamente, boa parte da problemática levantada aqui, acerca da tríade canônica e do seu uso no ensino de roteiro para cinema e AV. A permanência do ensino da tríade canônica, com sua respectiva "paternidade" atribuída à Poética, de Aristóteles, em cursos de teoria e prática de roteiro no Brasil, talvez seja produto desses mesmos processos de "escolarização" e "sincretização" (DENIZOT, 2010). Em alguns casos, a tríade é associada à poética de Aristóteles no sentido de "compactar" um percurso histórico deveras complexo e nuançado, com passagem obrigatória por Batteux, Steiger, os irmãos Schlegel, por Goethe, por Hegel e demais teorias românticas de gênero, mas que resulta “abreviado" em algumas ocasiões - e não são raras essas ocasiões, acreditamos, uma vez que temos dúvidas quanto à passividade desse tema nos currículos universitários de ensino de roteiro para cinema e AV.

Quando e exatamente por que isso ocorre são questões que fogem à capacidade e ao espaço deste breve estudo, mas que talvez mereçam alguma reflexão futura mais detida no âmbito específico do ensino da teoria e prática do roteiro no Brasil. O que referimos como vulgata da tríade, ou "abreviatura" de um percurso histórico, talvez tenha razões baseadas no que discutimos até aqui. Talvez possa ser em parte atribuído, no caso brasileiro, a uma leitura mais apressada da diferenciação que Anatol Rosenfeld faz dos gêneros lírico, épico e dramático, bem como da dupla acepção de cada termo: a substantiva e a adjetiva (ROSENFELD, 1985; PONTES, 2010, p. 3). Em linhas mais gerais, a mesma abreviatura ou

\footnotetext{
${ }^{19}$ No original : “c'est ainsi que subsiste toujours le modèle de la « triade » (épique, lyrique et dramati- que, reformulé pour intégrer les genres de la prose en roman, poésie et théâtre), qui, en se calquant sur la tradition rhétorique des trois genres (judiciaire, délibératif et dé- monstratif), est devenu au XIXe siècle un cadre essentiel pour catégoriser les genres dans les ouvrages scolaires [...]".
} 
insistência na vulgata da tríade pode ter alguma relação com o conceito mais amplo que Bakthin chamou de "romancização" (BAKHTIN, 1998; PONTES, 2010). É assim que “[...] o romance introduz uma problemática, um inacabamento semântico específico e o contato vivo com o inacabado, com a sua época que está se fazendo (o presente ainda não acabado)" (BAKHTIN, 1998, p. 400). Talvez a "romancização" - cujo impacto nas artes cinemáticas e sua respectiva conjugação de uma "épica" com uma "dramática" (um regime "misto", porventura algo análogo à classificação platônica, muito anterior) não nos parece desprezível - também possa ter tido seu papel na dimensão pedagógica do ensino de roteiro para cinema e $\mathrm{AV}$, igualmente merecedor de reflexão mais detida em alguma outra oportunidade. Remetemos aqui novamente a Rosenfeld (1985) e a Bakthin (1998), mas também ao artigo de Pontes (2010).

Nesse sentido, e talvez ainda em tempo, o conceito de "amphitextualitê" (algo que poderíamos traduzir como "anfitextualidade", mantendo-se no horizonte semântico a classe mesma dos animais anfíbios) de Denizot talvez possa ajudar a esclarecer a controvérsia. A amphitextualité de Denizot consiste num conceito que visa a descrever as "solidariedades textuais" dentro das quais textos e gêneros são entendidos. Concerne, portanto, a um sexto tipo de relação transtextual, somada ao modelo de cinco relações definidas por Genette (1982, p. 11-12): métatextualité, hypertextualité, paratextualité, intertextualité e architextualité.

\begin{abstract}
A esses tipos de relacionamentos, adiciono aquele que vincula um texto a um ou mais textos ao lado do qual ele é colocado, um relacionamento que não é puramente paratextual (já que cada um dos textos também pode ser acompanhado por um paratexto), mas que é contextual e que nomeio, no mesmo modelo e para designar especificamente esse tipo de "contextualidade": anfitextualidade [amphitextualité] (do grego antigo anfi: ao redor, de ambos os lados). Agora, no caso de gêneros textuais, esses fenômenos de anfitextualidade são importantes, porque textos e gêneros, raramente isolados, são assim apanhados em redes que podem modificar o ponto de vista que temos sobre eles. (DENIZOT, 2010, p. 222, tradução nosa). ${ }^{20}$
\end{abstract}

O conceito de "anfitextualidade", explica Denizot, permite sobretudo abordar mais claramente a construção dos gêneros literários dentro dos manuais de literatura (e aqui, em nosso caso, vale o paralelo com manuais de roteiro), para melhor compreender como são

\footnotetext{
${ }^{20}$ No original: "À ces types de relations, $j$ 'ajoute celle qui relie un texte à un ou plusieurs textes à côté desquels il est posé, relation qui n'est pas purement paratextuelle (puisque chacun des textes peut aussi être accompagné d'un paratexte), mais qui est d'ordre contextuel et que je nomme, sur le même modèle et pour désigner spécifiquement ce type de «contextualité» : l'amphitextualité (du grec ancien amphi: autour de, des deux côtés) Or, dans le cas des genres textuels, ces phénomènes d'amphitextualité sont im- portants, parce que les textes et les genres, rarement isolés, sont ainsi pris dans des réseaux qui peuvent modifier le point de vue que l'on a sur eux".
} 
construídos e reconfigurados os gêneros segundo seus usos e as configurações disciplinares às quais devem ser adequados. Denizot exemplifica esse argumento com a referência à análise que ela mesma fez do ensino da tragédia clássica nos currículos franceses (DENIZOT, 2010, p. 223). No caso dos gêneros literários e textuais, continua Denizot, a anfitextualidade revela mais claramente um fenômeno recorrente:

[...] nomear, definir e delimitar um gênero é, em princípio, repousar um certo olhar sobre um texto. De certa maneira, os gêneros são uma questão de ponto de vista. Tal texto, segundo o ponto de vista que adotamos, pode pertencer a este ou àquele gênero, e tal gênero, segundo o ponto de vista que adotamos, pode ser descrito como um tal outro gênero. (DENIZOT, 2010, p. 226, tradução nossa). ${ }^{21}$

Denizot (2010) praticamente conclui seu artigo (derivado de uma pesquisa de doutorado) afirmando que, "[d]ito de outra forma, são as mudanças de finalidades disciplinares que conduzem à mudança dos objetos escolares, ou a reconfigurá-los” (p. 227). ${ }^{22}$ Convém salientar a importância que Denizot reconhece na ideologia reinante, em cada época estudada, sobre os currículos escolares por ela avaliados, entre 1802 e 2008.

\section{Considerações finais}

Nossa primeira hipótese acerca da permanência da vulgata da tríade - a da "compactação" de um percurso histórico deveras complexo e nuançado -, acrescida do conceito de "anfitextualidade" de Denizot (2010), pode ser acoplada a um segundo entendimento, o de que o pensamento romântico (e.g. HEGEL, 1980; SCHILLER, 1991) talvez tenha sido determinante e muito influente, até hoje, desde que os currículos universitários de ensino da teoria e prática do roteiro para cinema e AV começaram a ser criados, não apenas no Brasil, mas anteriormente em outros países (anos 1960 e 1970). A importância e a prevalência até hoje, primeiro de uma "política dos autores" (TRUFFAUT, 2005; BAZIN, 1987), depois de uma "teoria de autor" (SARRIS, 1963a e 1963b; SARRIS, 2009), no âmbito da crítica e dos estudos de cinema e AV, no Brasil e no mundo, seriam, portanto, talvez, assuntos correlatos.

Sendo assim, neste breve artigo, recorremos a Genette (1990), Stalloni (2001),

\footnotetext{
${ }^{21}$ No original: "[...] nommer, définir et délimiter un genre, c'est tout d'abord poser un certain regard sur un texte. D'une certaine manière, les genres sont affaire de point de vue. Tel texte, selon le point de vue que l'on adopte, peut appartenir à tel ou tel genre, et tel genre, selon le point de vue que l'on adopte, peut être décrit comme tel autre genre".

${ }^{22}$ No original: "Autrement dit, ce sont les changements des finalités disciplinaires qui conduisent à changer les objets scolaires, et/ou à les reconfigurer".
} 
Compagnon (2001), Jenny (2003), Guimarães (2009) e Denizot (2010), entre outros autores, para tentar elucidar um pouco dos modelos platônico e aristotélico, desfazendo o engano de que a tríade canônica (o lírico, o épico e o dramático) seria proveniente da Poética, de Aristóteles. Resta claro, a partir da leitura de Genette (1990), que são a divisão romântica e pós-romântica que de fato encaram o lírico, o épico e o dramático não mais como modos de enunciação, mas como verdadeiros gêneros, em definições que comportam também elementos temáticos, por mais vagos que sejam.

Todavia, permanece a pergunta: por que tal engano subsiste? Os motivos poderiam ser encontrados puramente no processo de geração de vulgatas escolares investigado por Denizot (2010)? A despeito dos oportunos esclarecimentos de Genette (1990), Denizot (2010) e outros autores, por que a tríade (épico, lírico e dramático) continua aparecendo em currículos ou programas de cursos universitários, em websites ou em livros com foco sobre a teoria e a prática do roteiro para cinema e AV?

Obviamente, e Genette (1990) esmiuça essa motivação primeva, a atribuição de um cânone a Platão e Aristóteles angaria prestígio. Assim o foi no âmbito dos estudos literários e, muito provavelmente, trata-se do mesmo caso nos estudos de cinema. Não obstante, após a elucidação do equívoco por parte de alguns autores (e.g. GENETTE, 1990; STALLONI, 2001; GUIMARÃES, 2009; DENIZOT, 2010), e a reboque de uma eventual leitura mais atenta de alguma boa tradução da Poética, volta e meia o engano reaparece, em publicações ou processos de formação de profissionais em cinema e AV (pagos ou gratuitos, presenciais ou online). Talvez a vulgata da tríade canônica seja mais persistente e pervasiva nos estudos de cinema do que nos estudos literários, embora não tenhamos dados comprobatórios dessa suspeita para o presente momento.

De toda maneira, parece razoável supor que a sobrevivência do que estamos aqui a chamar de vulgata da tríade canônica (a atribuição dos gêneros lírico, épico e dramático a Aristóteles) deva-se a uma resistência difusa em reler e rever textos-chave, sobretudo obras “originais". Por “originais", referimo-nos a autores tomados como pioneiros naquilo que diga respeito a um dado pensamento, termo, conceito ou teoria. Isso implica dizer que, talvez, graças a uma "indústria da hermenêutica" que "pasteuriza" autores originais, diversas ideias e conceitos perdem seu contexto, até mesmo seu nexo, e acabam degradadas em algo secundário, terciário, e até mesmo distorcido. Não é a primeira vez, nem a última, supomos, em que o desaviso em relação a pensamentos originários (neste caso, o aristotélico) provoca alguma controvérsia ou algum "ruído" no âmbito dos estudos de cinema e AV. Nesse sentido, 
parece valer a ideia de que, na dúvida, convém retomarmos alguns percursos teóricos por precaução, ou "beber direto na fonte", a fim de evitar elos perdidos - elos que, com o passar do tempo, podem vir a implicar, também, nexos perdidos.

\section{Referências}

ALMEIDA, Aryelle. Literatura: o que é, funções e gêneros literários. In: Portal Medium. 9 ago. 2019. Disponível em: https://medium.com/@aryellealmeida7/literatura-o-que-\%C3\%A9fun\%C3\%A7\%C3\%B5es-e-g\%C3\%AAneros-liter\%C3\%A1rios-c7d005131d5a. Acesso em: 2 mai. 2020.

ARISTÓTELES. Poética. Lisboa: Fundação Calouste Gulbenkian, 2008.

ARISTÓTELES; HORÁCIO; LONGINO. A poética clássica. São Paulo: Cultrix, 2005.

BAKHTIN, Mikhail. "Epos e romance (sobre a metodologia do estudo do romance)". In: BAKHTIN, Mikhail. Questões de literatura e de estética (A teoria do romance). 4. ed. São Paulo: Ed. UNESP, 1998, p. 397-427.

BARTHES, Roland. O rumor da língua. São Paulo: Martins Fontes, 2012.

BATTEUX. Les Beaux-Arts réduits à un même principe. Paris: Durand, 1746.

BAZIN, André. Qu'est-ce que le cinéma ? Paris: Seuil, 1987.

BEHRENS, Irina. Die Lehre von der Einteilung der Dichtkunst vornehmlich vom 16. bis 19. Jahrhundert: Studien zur Geschichte der poetischen Gattungen. In: Beihefte zur Zeitschrift für romanische Philologie, 1940, s/p.

CASTRO, Renato Luís de. Gêneros literários. Portal Curso Enem Gratuito, online. s/d. Disponível em: https://cursoenemgratuito.com.br/generos-literarios/. Acesso em: 13 mai. 2020.

CHERVEL, A. "En quoi une culture peut-elle être scolaire?". In: JACQUET-FRANCILLON, F.; KAMBOUCHNER, D. (Orgs.). La crise de la culture scolaire. Paris: PUF, 2005, p. 77-85.

CHERVEL, A. "L'histoire des disciplines scolaires. Réflexions sur un domaine de recherche". Histoire de l'éducation, Paris, INRP, n. 38, p. 59-119, 1988/1989.

COMPAGNON, M. A. Théorie de la littérature: la notion de genre. UFR de Littérature française et comparée/Cours de licence LLM 316 F2. Paris: Université de Paris IV-Sorbonne, 2001. Disponível em: https://www.fabula.org/compagnon/genre.php. Acesso em: 29 abril.2020.

COMPARATO, Doc. Da criação ao roteiro: teoria e prática. São Paulo: Summus, 2009.

DENIZOT, Nathalie. Genres littéraires et genres textuels dans la discipline français. Pratiques, Paris, n. 145/146, 2010, p. 211-230. Disponível em: https://journals.openedition.org/pratiques/1562 . Acesso em: 11 mai. 2020.

DIANA, Daniela. Gêneros literários. Toda matéria, 21 de setembro de 2018. Disponível em: https://www.todamateria.com.br/generos-literarios/. Acesso em: 2 mai. 2020. 
EDGAR-HUNT, Robert; MARLAND, John; RAWLE, Steven. A linguagem do cinema. Porto Alegre: Bookman, 2013.

FIELD, Syd. Manual do roteiro. Rio de Janeiro: Objetiva, 1995.

FORSTER, E. M. Aspectos do romance. Rio de Janeiro: Globo, 2005.

FRYE, Northrop. Anatomia da crítica. São Paulo: Cultrix, 1973.

GENETTE, Gérard. Introdução ao arquitexto. Lisboa: Vega, 1990.

GUIMARÃES, Roberto Lyrio Duarte. Primeiro traço: manual descomplicado de roteiro.

Salvador: Edufba, 2009.

HEGEL, G.W.F. Estética. Poesia. Lisboa: Guimarães \& C Ed., 1980.

JENNY, Laurent. Méthodes et problèmes : les genres littéraires. Genève: Université de Genève, 2003.

KNUPP, D. "Xtensivo Literatura Gêneros Literários". Canal ProjetoX, 16/07/14. Disponível em: https://www.youtube.com/watch?v=rBtgw_3rpY4\&feature=youtu.be. Acesso em: 13 mai. 2020.

KUENTZ, P. L'envers du texte. Littérature, n. 7, Le discours de l'école sur les textes. Paris: Larrousse, 1972, p. 3-26.

LODGE, David. A arte da ficção. Porto Alegre: L\&PM, 2010.

MOTA, Marcos. Gêneros literários, 8 de dezembro de 2013. Disponível em:

http://marcosmota.com.br/wp/generos-literarios/. Acesso em: 9 junho de 2019.

MUSTEFAGA, Rafaela. Gêneros literários - O que são? Tipos e Exemplos. Portal Gestão

Educacional, online. Disponível em: https://www.gestaoeducacional.com.br/generos-literarios/. Acesso em: 13 mai. 2020.

PALLOTTINI, Renata. Introdução à dramaturgia. São Paulo: Ática, 1998.

PLATÃO. A república. Rio de Janeiro: Nova Fronteira, 2016.

PONTES, Newton de Castro. A romancização do drama e suas implicações na escrita dramática moderna. Palimpsestos, n. 10, p. 1-18, 2010. Disponível em: https://www.e-

publicacoes.uerj.br/index.php/palimpsesto/article/view/35168. Acesso em: 11 de maio de 2020.

PROPP, V. I. Morfologia do conto maravilhoso. 2. ed. Rio de Janeiro: Forense Universitária, 2010.

ROSENFELD, Anatol. O teatro épico. São Paulo: Perspectiva, 1985.

SARRIS, Andrew. Notes on the Auteur Theory in 1962. In: BRAUDY, Leo; COHEN, Marshall (Eds.). Film theory and criticism: introductory readings. 7 ed. New York: Oxford Univ. Press, 2009, p. 451-454. 
SARRIS, Andrew. The American cinema. Film Culture, n. 28, p. 1-68, 1963a.

SARRIS, Andrew. The Auteur Theory and the Perils of Pauline. Film Quarterly, v. 16, N. 4, p. 26-33, 1963b. Disponível em:

https://www.jstor.org/stable/pdf/3185951.pdf?refreqid=excelsior\%3A08d147d55afa394e4391651 d9745f8c0. Acesso em: 13 mai. 2020.

SAUSSURRE, Ferdinand. Curso de linguística geral. São Paulo: Cultrix, 2006.

SCHILLER, Friedrich. Teoria da tragédia. 2 ed. Trad. Anatol Rosenfeld. São Paulo: E.P.U., 1991.

SOARES, Angélica. Gêneros literários. 6 ed. São Paulo: Ática, 2000.

SOUZA, J. Filmes de Gêneros para Roteiristas: o que você precisa saber para começar a escrever um roteiro de gênero. Portal Tertúlia Narrativa, 18 de janeiro de 2018. Disponível em: https://www.tertulianarrativa.com/single-post/2018/01/18/Filmes-de-G\%C3\%AAneros-paraRoteiristas-O-que-voc\%C3\%AA-precisa-saber-para-escrever-um-roteiro-de-g\%C3\%AAnero. Acesso em: 8 jun. 2019.

STAIGER, Emil. Conceitos fundamentais da poética. Rio de Janeiro: Tempo Brasileiro, 1977.

STALLONI, Yves. Os gêneros literários: A comédia, o drama, a tragédia. O romance, a novela, os contos. A poesia. Rio de Janeiro: Difel, 2001.

TODOROV, Tzvetan. (Org.). Teoria da literatura: textos dos formalistas russos. São Paulo: Ed. Unesp, 2013.

TODOROV, Tzvetan. As estruturas narrativas. São Paulo: Perspectiva, 2011.

TODOROV, Tzvetan. Introdução à literatura fantástica. São Paulo: Perspectiva, 1970.

TODOROV, Tzvetan. Os gêneros do discurso. São Paulo: Martins Fontes, 1980.

TRUFFAUT, François. O prazer dos olhos: escritos sobre cinema. Rio de Janeiro, JZE, 2005.

Recebido em: 25/12/2021

Aceito para publicação em: 24/03/2021 